\title{
Reluctant Feminists? Islamist MPs and the Representation of Women in Kuwait after 2005
}

\author{
Rania Maktabi \\ Østfold University College \\ rania.maktabi@hiof.no
}

\begin{abstract}
Drawing on theories of representation in general, and "the politics of presence" perspective in particular, this article explores whether and how female parliamentarians in Kuwait influenced male MP s to support female civil and economic rights after women's enfranchisement in 2005 .

A review of parliamentary documents between 2006 and 2016 reveals that a sharp rise in the number of law proposals occurred in the parliamentary Family and Woman Affairs Committee (FWAC) after the four first-ever female legislators were elected in 2009. Roughly half of all issues regarding women's interests -45 per cent - over the past decade were raised during the two years when women were present in the Kuwaiti parliament.

In explaining this fact, the paper argues that male Islamist MPs acted as reluctant feminists and diligent opportunists by responding to new opportunities and expectations created by the presence of female MPs. Islamist MPs reformulated demands pertaining to poverty alleviation and social assistance by focusing on women as mothers, widows, and caregivers. They emphasized gender relations in ways where Kuwaiti women, particularly those married to non-Kuwaitis and stateless bidun, were seen as capacitated citizens. Kuwaiti women, some Islamist MPs argued, should be able to act as legal guardians ( $k a f i l)$ of their husbands and children, be brokers of material welfare services such as free education and health services, and get access to public housing. After the exit of female MPs from parliament in 2011, Islamist MPs stopped arguing along these lines, and their demands on behalf of women through the FWAC dropped sharply.
\end{abstract}

1 This article is written in loving memory of Moontyger-mentor Mary Ann Tétreault, Professor of International Affairs at Trinity University in Texas, who passed away on 11 November 2015. 


\section{Keywords}

Kuwait - women - parliament - citizenship - Bidun - representation - women's interests - Islamists

\section{Introduction}

What is the impact of women's enfranchisement on the prioritization of women's interests in representative institutions? What is the nature of the relationship between the descriptive representation of women (i.e. the number of women elected, and their substantive representation - i.e. the articulation of women's interests widely defined as conditions, needs, and concerns that expand the autonomy of female citizens)? In The Politics of Presence, political scientist and feminist philosopher Anne Phillips discusses whether and how the inclusion of a politically marginalized group, here specified as the social category of women, contributes to challenging and modifying public policy. ${ }^{2}$ Her insights are fruitful in considering the impact of Kuwaiti women's enfranchisement in 2005, and the election of four female MP s between 2009 and 2011. Drawing on theories of representation in general, and on Phillips's "politics of presence" perspective in particular, I suggest that male MPs focused more intensely on women's interests when women were elected to the Kuwaiti parliament. ${ }^{3}$ This observation is corroborated by my review of documents issued by the parliamentary Family and Woman Affairs Committee (FWAC, lajnat shu'ūn al-usra wa-l-mar'a) between 2006 and 2016, which shows that male MPs, including Islamists who had previously voted against women's enfranchisement, raised proposals pertaining to women's interests more frequently in the twoyear period during which four women were legislators. In short, this article investigates whether and how Kuwaiti women's enfranchisement in 2005, and ensuing representation in parliament in 2009 , shaped the articulation of women's interests in the Kuwaiti legislative assembly.

Although authoritarian rule has re-emerged in new ways, pressure for reforms in Kuwait persists through parliamentary activism where legislators continuously protest against corruption and engage in debates on public bud-

2 Anne Phillips, The Politics of Presence, Oxford Political Theory (Oxford: Clarendon Press, 1995), 182. A 'feminist' is here understood as an individual who acts in pressing for women's interests by seeking to expand a woman's autonomy and legal capacity.

3 The Kuwait parliament is called Majlis al-Umma al-Kuwaytī / Kuwaiti National Assembly (KNA). Official website: <http://www.kna.kw/clt-html $5 /$ index.asp >; all references from the Internet were last retrieved on 15 December 2016. 
gets. ${ }^{4}$ Kuwaiti parliamentary documents offer textual imprints of political issues raised in public, how they were framed and articulated, and the timing in which they were presented. The primary sources of my investigation are reviews of suggestions and law proposals raised in the FWAC between July 2006 and June 2016. 5

Kuwaiti MPs are able to express opinions and suggest legislation through questions (as'ila), expressions of support (iqtirāh bi-raghba), and law proposals (iqtirāh bi-qānūn or mashrü' bi-qānūn), which are then passed to an appropriate parliamentary committee (lajna). If accepted by the committee, the proposal is presented in a plenary session, voted on in two separate rounds, and then approved by the government before being issued as law published in the Official Gazette (al-jarìda al-rasmiyya). ${ }^{6}$

In the following, I first introduce features of Kuwaiti society and politics, followed by a presentation of Islamist groups, and the composition of the Kuwaiti parliament from 2009 to 2011, when four female MPs served as legislators. In the second section, I set out theoretical approaches on women's political representation. The third section renders a table on the types of issues raised over a decade in the FWAC. An analysis of some of the most frequently raised demands pertaining to women's interests is presented in the fourth section. In the fifth section, I discuss the politics of presence thesis and the political impact of female political representation in Kuwaiti politics. The sixth section reflects on whether and how Islamists act as reluctant feminists in light of parliamentary documents, followed by a conclusion.

\section{On Kuwaiti Politics, State, and Society}

Among the Gulf states, Kuwait has an unparalleled historical record of political participation and a rich heritage of autonomous and semi-autonomous organizations. The constitution, formed in 1962, a year after independence from British protectorate rule in 1961, delineated the powers of the ruling Ṣabāh

4 Mary Ann Tétreault, "Political Activism in Kuwait: Reform in Fits and Starts", in Taking to the Streets: The Transformation of Arab Activism, eds. Lina Khatib and Ellen Lust (Baltimore:Johns Hopkins University Press, 2014), 283-85.

5 Parliamentary documents are accessible at the Kuwaiti National Assembly's website (<http:// www.kna.kw>) through the entry key ibhāth fi-l-wathä'iq al-barlamāniyya. I thank Mr Ahmad al-Saffar at the KNA's Documentation Unit who instructed me on how to use the website during my fieldwork in Kuwait between 20 February and 6 March 2014.

6 'Law proposals' and 'expressions of support' are categorized as 'proposals' in this article. The policy outcome of selected, not all, proposals is presented and discussed here. 
family (Āl Șabāḥ) and main merchant families. After 1962, elections to the National Assembly have been carried on, with interruptions in 1976 and 1986, when the emir dissolved the parliament. ${ }^{7}$ Parliamentary life resumed in 1992, after the Iraqi invasion of Kuwait in 1990, and continues to evolve despite turmoil in the wake of the 2011 Arab Uprisings. ${ }^{8}$

The demographic constitution of the Kuwaiti state is of political importance for two reasons. First, citizens form a minority of around 35 per cent of the state's 3.1 million inhabitants, while migrants and long-term non-citizens from the MENA region and Asia constitute around 80 per cent of the workforce. ${ }^{9}$ Second, the divide between citizens and non-citizens has been blurred following the establishment of the modern state in the 1940 s and the enactment of the 1959 Nationality Law. Unsettled territorial boundaries, politically motivated naturalization and denaturalization policies practised by the regime since the 196os, and the politicization of census figures after Kuwait's liberation from the Iraqi occupation, are three factors that have given rise to a significant bidun population, a group of long-term residents that numbers between 100,000 and $200,000 .{ }^{10}$ This group of denizens ${ }^{11}$ - stateless non-citizens who are part of the Kuwaiti social fabric - are significant to this study because, as will be elaborated on below, they figure recurrently in proposals raised by MPs through the FWAC.

The Kuwaiti parliament has 65 seats: 50 MPs are elected, while 15 ministers are appointed by the emir.

8 Kuwait's Moment of Truth, ed. Marc Lynch, The Project on Middle East Political Science (POMEPS), (Washington, DC: Institute of Middle East Studies, George Washington University, 2012).

9 The Kuwaiti Central Statistical Bureau estimates the Kuwaiti population at 3.3 million, including approximately 1.3 million Kuwaitis (35 per cent) and 2.1 million non-Kuwaitis (65 per cent). Annual Statistical Abstract 2012 <http://www.csb.gov.kw/Socan_Statistic_ EN.aspx?ID=18,\%2047, 99, 101>.

Bidun is Arabic for bi-dūn jinsiyya, meaning "without citizenship." According to Human Rights Watch, there are 105,702 bidun in Kuwait, although the number is most probably higher, and closer to 250,000, due to the politicization of census figures. See "World Report 2014, Kuwait” <https://www.hrw.org/world-report/2014/country-chapters/kuwait>. For a comprehensive study on statelessness in Kuwait, see Claire Beaugrand, "Statelessness and Transnationalism in Northern Arabia: Biduns and State Building in Kuwait, 1959-2009" (PhD diss., London School of Economics, 2010). For an analysis of the number of bidun who were excluded from the Kuwaiti citizenry after 1991, see Rania Maktabi, "The Gulf Crisis (1990-91) and the Kuwaiti Regime” (MPhil diss., University of Oslo, 1992), 97-101.

11 Tomas Hammar, Democracy and the Nation State: Aliens, Denizens and Citizens in a World of International Migration (Aldershot: Avebury, 1990), 12-14, denotes 'denizens' as privileged resident aliens. 


\section{Islamists and the Kuwaiti Political Scene}

The upsurge of political Islam after 1980 bolstered the influence of Islamist groups such as the local branch of the Muslim Brotherhood, the Islamic Constitutional Movement (al-Haraka al-Dustūriyya al-Islämiyya), known by its Arabic acronym Hadas. A second group of Islamists are Salafists who, since the turn of the millennium, have been increasingly articulate proponents of puritanical understandings of Islam, particularly theological viewpoints supported by the political regime in Saudi Arabia. ${ }^{12}$ Urbanized citizens with tribal Bedouin backgrounds have given rise to a third group of Islamic-oriented MPs. ${ }^{13}$ 'Islamist' more for their conservative observance of faith than religious ideological fervour, these tribalist constituencies have gained electoral political strength in the past decade.

Hence, in this study, the term 'Islamist' denotes MPs who are supported by, or affiliated with tribal, Salafi, or Hadas groups. Whereas members of Hadas and Salafists may differ on theological underpinnings, both are considered predominantly loyal to the ruling Āl Șabāḥ. By contrast, previously reliable pro-government tribalist groups have, since 2006 , repeatedly challenged the ruling regime. Residents of tribal constituencies, and tribal MPs with populist and nationalist credentials, were, for instance, deeply involved in the storming of the Kuwaiti parliament in November 2011 in protest against a corruption scandal involving the prime minister. ${ }^{14}$

In general, Islamists share common conservative ideologies regarding gender roles in the family: the woman is seen primarily as a homemaker, and the man is perceived as the principal financial provider and the head of the household $\left(m u^{c} i l\right)$. Patriarchal family models are further bolstered by gendered state laws - such as the 1984 Kuwaiti Personal Status Law, the 1959 Nationality Law, and penal and social security laws - and underpinned by invocations of traditional interpretations of Islamic jurisprudence where male kin are custodians and mediators of female legal, civil, and social rights..$^{15}$

12 Salafi groups constitute not a movement (haraka) but rather an intellectual current (tayyār fikrî) concerned with issues related to social behaviour. Fairly united until 1990, Salafi groups became increasingly split over political issues after Kuwait's liberation from the Iraqi occupation in 1991. Zoltan Pall, Kuwaiti Salafism and Its Growing Influence in the Levant, (Washington, DC: Carnegie Endowment for International Peace, 2014), 4-8.

13 The distinction between 'Islamist' and 'Islamic oriented' is introduced by Anne Sofie Roald, "Benevolent Patriarchy': Palestinian Women between 'Ideal' and 'Reality", Islam and Christian-Muslim Relations 24, no.3 (2013), 336, doi: 10.1080/o9596410.2013.788275.

Tétreault, "Political Activism", 285; “Kuwait cabinet resigns amid political crisis”, Al-Jazeera 28 November $2011<$ http://www.aljazeera.com/news/middleeast/2011/11/20111128112619355 $567 . \mathrm{html}>$. 
The Islamization of the public sphere in Kuwait has impacted gender relations since the turn of the millennium. ${ }^{16}$ For instance, gender segregation in post-secondary public schools and universities did not exist before a legal amendment, raised and voted on in parliament in 1996, imposed gendered sexuality norms outside the realm of the family. Since 1992, Islamist MPs have repeatedly voted down proposals to grant women political rights. On 16 May 2005 , the enfranchisement of women was eventually passed in parliament, despite the opposition of Islamist MP s. ${ }^{17}$

In October 2015, a few months after Kuwaiti women were enfranchised, the Woman's Affairs Committee (WAC) (lajnat shu'ün al-mar'a) was established by MP Șālih 'Ashūr (b. 1953), a vocal supporter of women's rights and a prominent Shi'a representative of the Justice and Peace Alliance (tajammu' al-'adäla wa-lsaläm). Two years later, 'family' was added, and the wc became the Family and Woman's Affairs Committee (FWAC). For the first time in Kuwaiti parliamentarian life, women's issues were framed in ways that took as a point of departure the interests, needs, and concerns of women seen as a social category. Importantly, although Kuwaiti women's interests had been addressed previously, women as a category were to a lesser degree profiled as primary subjects of concern, and proposals related to women were raised in different parliamentary committees, such as those addressing health, social, education, and housing issues.

of Middle East Studies 1, no.1 (2016), 20-34 <http://journals.lub.lu.se/index.php/nidaba/ article/view/15846>; Badriya al-'Awaḍī, al-Huqūq al-siyāsiyya wa-l-qānūniyya wa-l-insāniyya li-l-mar'a al-kuwaytiyya (Kuwait: privately published, 2006), 55-57, 208-10, 27.

Mary Ann Tétreault, "Kuwait: Sex, Violence, and the Politics of Economic Restructuring", in Women and Globalization in the Arab Middle East: Gender, Economy \& Society, eds. Eleanor Abdella Doumato and Marsha Pripstein Posusney (Boulder, London: Lynne Rienner Publishers, 2003), 215-38.

More than 20 elected Islamist MPs voted against, while 21 elected MPs and 14 appointed ministers voted for extending the franchise to women. Doron Schultziner and Mary Ann Tétreault, "Paradoxes of Democratic Progress in Kuwait: The Case of the Kuwaiti Women's Rights Movement", Muslim World Journal of Human Rights 7, no.2 (2011), doi:10.2202/15544419.1192. For the political affiliation of MPs and voting results, see Michael Herb's superb Kuwait Politics Database <http://kuwaitpolitics.org/positions2o.htm>. See also Rania Maktabi, "You've Come a Long Way, Babe: A Decade of Women's Enfranchisement in Kuwait", New Middle East Blog, 5 March 2015 <https://newmeast.wordpress.com/2015/03/ 05/youve-come-a-long-way-babe/>. 


\section{The Composition of the Kuwaiti Parliament, 2009-2011}

More than 25 women ran for office along with roughly 250 male candidates in the 2006 and 2008 parliamentary elections, but no woman received enough votes to be elected. The tide turned at the 2009 elections. Four women, Asil al'Awaḍī, Rūlā Dashtī, Salwa al-Jassār, and Ma'șūma al-Mubārak, entered parliament as the first-ever elected female legislators in Kuwaiti political history. ${ }^{18}$

The entry of four female MPs was accompanied by an overall loss of ten positions previously held by Salafi and Hadas MPs, while independent Islamists and conservatives with a tribalist background strengthened their presence in parliament. Roughly categorized, the 2009 elections saw Islamists winning 11 seats (down from 21), Shi'a groups winning 9 seats (up from 5 ), six tribal groupings holding 20 seats between them, and liberals holding 8 seats (up from 7$) \cdot{ }^{19}$

Some factors shed light on the drop in the representation of Islamist groups: most political groups dissolved during campaigning for the benefit of independent candidacy. This change brought a surprising number of newcomers; voter turnout - the electorate counts roughly 385,800 registered voters - dropped from a norm of around 80 per cent to 60 per cent. Also, the regime attempted to mould the election results in its favour through bribes and political favours to candidates of tribal districts, as well as through a disproportionate coverage of pro-regime female candidates in the media as compared to male candidates. $^{20}$

\section{The Political Representation of Women and Women's Interests}

The representation of women and the representation of women's interests are two separate, but entangled, analytical approaches towards studying women's political participation. For one, women's interests are "not fixed but [...] con-

18 Mary Ann Tétreault and Mohammed Al-Ghanim, “The Day after 'Victory': Kuwait's 2009 Election and the Contentious Present", Merip Report, 8 July 2009 <http://www.merip.org/ mero/meroo70809?ip_login_no_cache=f1855d178316b8ba899d48f5a91c293f $>$; Rania Maktabi, "Female Citizenship and the Franchise in Kuwait after 2005", in The Crisis of Citizenship in the Arab World, eds. Roel Meijer and Nils A. Butenschøn (Leiden/Boston: E. J. Brill, 2017).

19 Inter-Parliamentary Union, Kuwait, Elections 2009 <http://www.ipu.org/parline-e/re ports/arc/2171_og.htm>; Michael Herb's Kuwait Politics Database, 2009 elections <http:// www2.gsu.edu/ polmfh/database/maj20ogoo.htm>.

20 Kjetil Selvik, Jon Nordenson, and Tewodros Kebede, "Print Media Liberalization and Electoral Coverage Bias in Kuwait", The Middle East Journal 69, no.2 (2015), 255-76, doi: 10.3751/69.2.15. 
structed through political processes over time."21 Also, there is no consensus among researchers on whether a policy outcome favourable to women is contingent on the presence of women in parliament - a point which is at the heart of discussions on descriptive and substantive aspects of women's representation.

\section{Descriptive and Substantive Representation of Women}

Research on women's political representation differentiates between two approaches towards studying the impact of women's political participation in representative institutions. ${ }^{22}$ Descriptive representation focuses on the barriers that inhibit women's electoral representation, such as the process of party recruitment, use of resources, and motivations that lead to representative positions. Substantive representation, meanwhile, explores the impact of women on politics. The latter approach suggests that, once in office, women would make a difference by acting for women by representing their interests. ${ }^{23}$

Lovenduski and Guadagnini perceive the two approaches as reflecting, on the one hand, the 'numbers' of women represented, and, on the other hand, 'acts' in support of women's issues irrespective of women's presence in decision-making bodies. According to them, recent research in Western liberal democracies suggests that acts, not numbers, are critical for reforms that strengthen female citizenship. ${ }^{24}$ However, Dahlerup challenges this finding, emphasizing the significance of an increase of female representatives into a 'critical mass' through fixed women's quotas. She argues that for women's representation to obtain substantive representation of women's interests, there needs to be a sufficiently large female presence. ${ }^{25}$

21 Louise Chappell and Lisa Hill, eds., The Politics of Women's Interests: New Comparative Perspectives (London: Routledge, 2006), 3.

22 Nina C. Raaum, "Gender Equality and Political Representation: A Nordic Comparison", West European Politics 28, no.4 (2005), 872-73, doi:10.1080/01402380500217003.

23 Joni Lovenduski and Pippa Norris, "Westminster Women: The Politics of Presence", Political Studies 51 (2003), 86-87, doi:10.1111/1467-9248.00414.

24 Joni Lovenduski and Marila Guadagnini, "Political Representation", in The Politics of State Feminism: Innovation in Comparative Research, eds. Amy G. Dorothy E., Mazur McBride (Philadelphia: Temple University Press, 2010), 164-66. For more on these diverging arguments, see Judith Squires, The New Politics of Gender Equality (Basingstoke: Palgrave Macmillan, 2007).

25 Drude Dahlerup, "Gender Quotas - Controversial but Trendy: On Expanding the Research Agenda”, International Feminist Journal of Politics 10, no.3 (2008), 322-28, doi:10.1080/146 16740802185643; Women, Quotas and Politics (Hoboken: Taylor and Francis, 2013). 
Phillips's thesis on the politics of presence represents an amalgamation of both approaches. She sees 'presence' and 'ideas', here understood as numbers and acts, not as mutually exclusive, but as complementary to a fairer system of representation. ${ }^{26}$ The politics of presence works, according to her, in tandem with the politics of competing ideas because "[g]roup interests, needs, preferences, or perspectives do not come to us ready-made by material conditions, and their representation is never absolved from processes of internal contestation and debate." 27 Phillips sees transformation and change evolve out of the interplay of numbers and acts that potentially create women-friendly policies. She does not point out specific means or mechanisms through which the politics of presence is attained, emphasizing rather the possibilities and opportunities that arise from interaction:

The hope (if not always the expectation) is that increasing the number of our representatives who come from disadvantaged groups will challenge and subsequently modify the basis on which public policy is defined. This can occur only in contexts which bring the differences together: where representatives who originate from one group are confronted with representatives who originate from another, and where the interaction between them produces something new. ${ }^{28}$

Hence, in the case of Kuwait, one may hypothesize that new entities and opportunities are likely to evolve out of the interaction between conservative Islamist MPs and the four elected female representatives. It then becomes essential to consider what women's interests are and how these are articulated in parliament.

\section{What are 'Women's Interests'?}

Lovenduski and Norris note that the concept of 'women's interests', though in need of being defined, remains controversial within feminist scholarship. In their study of the impact of an increase in the number of Labour Party women on British politics, they clarify that women's shared interests lie in policies that expand women's autonomy. ${ }^{29}$ Recognition of such interests may be described as a process of politicization consisting of three steps: (1) recognizing women as a group, (2) acknowledging the unequal balance of power between men and

\footnotetext{
26 Phillips, The Politics of Presence, 24-25.

27 Ibid., 173.

28 Ibid., 182.

29 Lena Wängnerud, “Testing the Politics of Presence: Women's Representation in the Swedish Riksdag", Scandinavian political studies 23, no.1 (2000), 70, doi:10.1111/1467-9477.00031.
} 
women, and (3) forming social welfare policies that increase the autonomy of female citizens. ${ }^{30}$

In Kuwait, the second component - acknowledging gender inequality - is not prominent outside liberal circles and the women's movement, but there is evidence of the first and third components, both of which materialized after Kuwaiti women were enfranchised. Women were recognized as a group (i.e. a distinct social category) when the parliamentary Woman's Committee was established in October 2005. Also, parliamentary records show that MPs raised, often successfully, proposals for social policy reforms that strengthened women's autonomy.

\section{The Parliamentary Family and Woman's Affairs Committee (FWAC)}

Since 2005, with the exception of the thirteenth parliamentary session (200911) - during which the four female MPs became the committee's main members, and Ma'șūma al-Mubārak assumed leadership - the FWAC has been headed by MP Șālih 'Āshūr. A review of proposals raised in the FWAC between 2006 and 2016 reveals three factors. First, Islamist MPs (i.e. legislators affiliated with Hadas, Salafi, or tribalist groups) were energetic in raising proposals. Second, roughly half of all issues (40 out of 9o) were raised in the two years during which female MPs served in parliament. Third, Islamists formulated claims and suggested social policy reforms by arguing for strengthened female autonomy and legal capacity. What is particularly intriguing is that male MPs who had voted against granting women political rights in 2005 became actively involved in articulating and raising female-specific issues. How can we understand their diligent behaviour in supporting Kuwaiti women's autonomy?

Phillips's politics of presence thesis, epitomized by the representation of four women in the Kuwaiti parliament between 2009 and 2011, may help to explain why male MPs formulated claims on behalf of women in new ways. Importantly, female MPs exerted influence over male MPs' acts subtly and indirectly. Three factors were crucial in this: the four women took over the FWAC, expectations rose among male MPs that "women should help women", ${ }^{31}$ and a more explicit emphasis was placed on rights-based arguments in support of Kuwaiti women's autonomy.

Islamist MPs formulated proposals in ways that emphasized women as capacitated citizens who could access social welfare benefits and support their families. Indirectly, perhaps even reluctantly, idealized and preferred patriar-

30 Lovenduski and Norris, “Westminster Women”, 87-88; Raaum, “Gender Equality”, 889.

31 Interview with Ṣaliḥ 'Āshūr, 18 March 2015. 
chal ideals of male providers gave way to a more prioritized objective: that of addressing the socio-economic hardships of households in which Kuwaiti women are married to non-citizens, including stateless bidun affiliated to Kuwaitis through tribal relations.

\section{Issues Raised in the Family and Woman's Affairs Committee (FWAC), 2006-2016}

What types of issues did MP s raise in the FWAC? Table 1 presents a categorization of needs and concerns regarding women's interests in the form of law proposals raised over the period.

The table shows that the most frequent demands were related to housing 23 in all. They were particularly articulated in the eleventh parliamentary session (i.e. right after women were enfranchised) and during the thirteenth session (i.e. while the four female MPs served in parliament). The other three major issues were related to the following: granting non-employed women a monthly grant (raised 15 times), maternity leave and increase in children's monthly allowance (raised on 13 occasions), and demands regarding Kuwaiti women married to non-Kuwaitis (raised 16 times). Issues concerning Kuwaiti women married to non-Kuwaitis were related to the provision of education and health services to their children, and expanding a Kuwaiti woman's capacity to guarantee, i.e. act as kafil, for the residency of her husband and children. ${ }^{32}$ In addition to the 16 proposals that single out Kuwaiti women married to nonKuwaitis, roughly half of all proposed housing issues mentioned the needs of this category of women in securing public dwelling. Notably, Kuwaiti women married to non-citizens is the category of women whose interests were most frequently addressed in the FWAC. ${ }^{33}$

\section{The Articulation of Women's Interests: Supporting Claims on Behalf of Female Citizens}

Two main findings crystallized after cross-checking the political background of MPs who submitted proposals at the FWAC between 2009 and 2011. First,

32 Kuwaiti nationality is transmitted only through male Kuwaitis. A Kuwaiti woman's children whose father is a non-Kuwaiti are therefore categorized as non-citizens and become subject to the kafäla system, the same as other non-citzens migrants. The kafäla is primarily an elaborate sponsorship system that regulates the entry and presence of the non-citizen workforce in all Gulf states but affects Kuwaiti women who marry non-Kuwaitis.

33 Kuwaiti women married to non-Kuwaitis figured in 6 out of 11 proposals raised by MPs between 2009 and 2011, amounting to more than half of all suggestions related to housing raised in the period during which women MPs were present in parliament. 


\begin{tabular}{|c|c|c|c|c|c|}
\hline Parliamentary session & $\begin{array}{l}11 \text { th } \\
12 \cdot 7 \cdot 2006 \\
-18.3 .2008\end{array}$ & $\begin{array}{l}\text { 12th } \\
1.6 .2008 \\
-17 \cdot 3.2009\end{array}$ & $\begin{array}{l}13^{\text {th }} \\
31.5 .2009 \\
-5.12 .2011\end{array}$ & $\begin{array}{l}\text { 14th } \\
6.8 .2013 \\
-22.6 .2016^{b}\end{array}$ & Total \\
\hline Housing & 12 & & 11 & & 23 \\
\hline $\begin{array}{l}\text { Monthly grant to non-work- } \\
\text { ing women }\end{array}$ & 4 & 5 & 6 & & 15 \\
\hline $\begin{array}{l}\text { Maternity leave / reduction } \\
\text { of working hours to } \\
\text { mothers / increase in } \\
\text { children's monthly } \\
\text { allowance }\end{array}$ & 5 & 2 & 6 & & 13 \\
\hline $\begin{array}{l}\text { Social assistance, free } \\
\text { access to health \& } \\
\text { education to husband } \\
\text { and children of Kuwaiti } \\
\text { woman married to } \\
\text { non-Kuwaiti }\end{array}$ & 2 & 2 & 6 & & 10 \\
\hline $\begin{array}{l}\text { Law on women's civil and } \\
\text { social rights }\end{array}$ & 1 & 5 & 1 & & 7 \\
\hline $\begin{array}{l}\text { Kuwaiti woman's capacity } \\
\text { to act as kafil and } \\
\text { guarantee residence of } \\
\text { non-citizen husband and } \\
\text { children }\end{array}$ & & & 5 & & 5 \\
\hline $\begin{array}{l}\text { Establishment of research } \\
\text { centre for women, } \\
\text { conferences, awareness } \\
\text { programmes }\end{array}$ & & 3 & 2 & & 5 \\
\hline $\begin{array}{l}\text { Financial insurance for } \\
\text { working women / widows }\end{array}$ & & & 2 & & 2 \\
\hline $\begin{array}{l}\text { Consultancy and service } \\
\text { centre for marital issues }\end{array}$ & & & & 4 & 4 \\
\hline $\begin{array}{l}\text { Divorced women's capacity } \\
\text { to get children's allow- } \\
\text { ance if children in her } \\
\text { custody (haḍāna) }\end{array}$ & & & 1 & & 1 \\
\hline
\end{tabular}




\begin{tabular}{|c|c|c|c|c|c|}
\hline Parliamentary session & $\begin{array}{l}\text { 11th } \\
\text { 12.7.2006 } \\
-18.3 .2008\end{array}$ & $\begin{array}{l}\text { 12th } \\
1.6 .2008 \\
-17 \cdot 3.2009\end{array}$ & $\begin{array}{l}13^{\text {th }} \\
31.5 .2009 \\
-5.12 .2011\end{array}$ & $\begin{array}{l}\text { 14th } \\
6.8 .2013 \\
-22.6 .2016^{b}\end{array}$ & Total \\
\hline $\begin{array}{l}\text { Restriction of women's } \\
\text { working conditions / } \\
\text { limit working hours at } \\
\text { night }\end{array}$ & 1 & & & & 1 \\
\hline Law on the Child & & & & 4 & 4 \\
\hline Total & 25 & 17 & 40 & 8 & 90 \\
\hline
\end{tabular}

a Categorization is according to the number of issues raised, not the number of proposals. MPs presented law proposals that sometimes covered several issues. For instance, Dr Fayṣal al-Muslim presented an expression of support on 15 June 2009 that a Kuwaiti woman married to a non-Kuwaiti should be enabled to guarantee residence of family members (i.e. act as guarantor - kafil - for her husband and children). In the same proposal he suggests that working mothers be given a raise in children's allowance ('alāwat $a w(\bar{a} d)$. This proposal is categorized as touching two issues. This methodological choice explains why the total number of proposals presented by MPs, and the number of issues categorized in the table, are not identical.

b The date 22 June 2016 refers to the date of writing, not the end date of the fourteenth parliamentary session.

female MPs suggested only three proposals through the FWAC: one for establishing a housing fund for women (proposed by all four female MPs on 28 April 2010), a second for addressing the social security of widows (proposed by Dashtī on 12 May 2010), and a third related to school registration of the children of Kuwaiti women married to bidun (proposed by al-Mubārak on 10 February 2011). Clearly, female MPs preferred other parliamentary committees as venues to forward demands for legislative reforms, including reforms that addressed women's interests. ${ }^{34}$ Second, Islamist MP s were among the most active in raising proposals between 2009 and 2011. Roughly half of MPS -20 of the 46 elected in 2009 - came up with proposals through the FWAC during the thirteenth parliamentary session. Of these, 18 MPs were affiliated with different shades of Islamist groups, ${ }^{35}$ of which a third - 6 MPs - were present in the 2005 enfranchisement session and had voted against extending the franchise to women. ${ }^{36}$

34 Maktabi, "Franchise in Kuwait after 2005", 446-53.

35 Half of them - 9 MPs - were affiliated to Islamist political groupings (Hadas, Kutlat altanmiya wa-l-ișlāh, and al-Kutla al-islāmiyya), while the other half had Salafi and tribal affiliations (al-Tajammu' al-islāmì al-salafı and al-Haraka al-salafiyya al-ilmiyya).

$3^{6}$ Two were affiliates of the Muslim Brotherhood (Fayṣal al-Muslim and Mikhlid al-'̄̄zimī); 


\section{Claims Proposed by Islamists: Articulating Women's Interests}

How did MP s suggest proposals in support of women's interests? A closer look at different sets of issues submitted to the FWAC sheds light on which issues were articulated as representing women's interests, and how these interests were argued for.

\section{i Monthly Grants to Non-employed Women}

The issue of a monthly grant (mukāfa'a shahriyya) was first presented in 2007 by independent tribalist MP Sa'dūn al-'Utaybī, who suggested that unemployed Kuwaiti women should receive $250 \mathrm{KD}$ a month for carework at home. ${ }^{37}$ After women's entry into parliament in 2009, Islamist MPs raised six proposals in support of grants to married and single women outside the paid labour market. The arguments and justifications they put forward in support of the proposals varied. For instance, one Islamist MP argued that monthly grants "safeguard and protect women and a dignified life as rendered in the noble Hadith by the Prophet Mohammed (be trusted in kindness to women) [...], and as pointed out in the Constitution, the family is society's fundament whose existence is protected by law whereby motherhood and childhood is shielded."38 Later, the same MP urges that parliament "support a woman's monthly revenue in face of high prices in local and international markets." ${ }^{39}$ Another Islamist MP seeks to "ease the burdens of daily life expenses (and) safeguard a dignified life for [the woman] and her children if her husband is Kuwaiti and unemployed, or if she is married to a non-Kuwaiti." ${ }^{40}$ According to a third Islamist, monthly grants to non-working women and mothers ensure that jobs become more available and "reduce pressures on employment opportunities in the Civil Service."41

Female MPs opposed monthly grant proposals, seeing them as discouraging female citizens from seeking work outside the home. These proposals were repeatedly voted down by the women MPs against the one vote by Ṣâlị 'Āshūr, the committee's secretary, and were therefore not forwarded to parliament to

two were Salafis (Ḍayfallāh Abū Ramiya and Walīd al-Ṭabāțabāīì), and two were tribalists (Musallam al-Barrāk and 'Alī al-Diqbāsī).

37 Corresponding to around 830 USD or 710 Euro in July 2017.

38 Mikhlid Rāshid al-'̄̄zimì (close to Hadas), 21 June 2009.

39 Mikhlid Rāshid al-'̄êzimī (close to Hadas) on 17 February 2010.

40 Dr. Fayșal al-Muslim, 6 July 2009.

41 'Askar al-'Anazī, 21 August 2009. 
be debated. ${ }^{42}$ Ma'ṣūma al-Mubārak saw it as a populist handout by Islamist and tribalist MPs. ${ }^{43}$

The issue was eventually settled through a decision issued by the Ministry of Labour and Social Affairs, which granted women over 55 a monthly allowance of $55^{\circ} \mathrm{KD} .{ }^{44}$ The ministerial decision conditioning that women be 55 years can be read as a way of placating cases related to poverty alleviation among older strata of women. The government thereby avoided the more politicized side effects of a grant that supports non-working younger women.

Proposals regarding housing reflect the economic centrality of access to public housing and rent-free loans, which is part of the social welfare services offered to Kuwaiti citizens through the state's Housing Law 47 of $1993{ }^{45}$ According to the Housing Law, a loan has to be registered in the names of both the husband and the wife. However, gender enters the housing equation because an administrative measure requires that the registration be made by the head of the household (rabb al-usra), which privileges the man, who normatively figures as the main provider $\left(m u^{i} i l\right)$. This measure empowers male Kuwaitis. Be they husbands, fathers, brothers, sons, or uncles, male Kuwaitis therefore prevail implicitly over the marital home. ${ }^{46}$

Pressures for reforming the shortcomings of the 1993 Housing Law have been pending since the law was issued. ${ }^{47}$ With women's enfranchisement in

The Fifth Protocol (al-Taqrìr al-khämis) of the FWAC, dated 8 September 2009 and signed by the committee's leader, Ma'șūma al-Mubārak, provides one example of three votes against and one pro-vote.

43 Interview with author, 22 April 2012.

44 Author interview with leader of the FWAC, Șāliḥ 'Āshūr, on 18 March 2015, who said: "We are still in favour of giving younger women monthly grants, and not only the older segments who are [in] reality grandmothers."

45 Sharifa Alshalfan, "The Right to Housing in Kuwait: An Urban Injustice in a Socially Just System" (Research Paper, London School of Economics, London, May 2013) <http://www. lse.ac.uk/middleEastCentre/kuwait/documents/The-right-to-housing-in-Kuwait.pdf>.

46 Author interview with lawyers Nivīne Márifī and Layla al-Rāshid, who deal with personal status cases in court where housing issues are part and parcel of custody cases over children, and right of abode in the marital home, 16 March 2015.

47 Kuwaiti women enjoyed more extensive housing rights to loans independently of male kin before the Iraqi invasion of Kuwait in 1991. Interview with law professor Badriya 'Abdallāh al-'Awaḍī, 15 March 2015. 
2005, pressure to reform increased, reflected in the suggestions raised through the FWAC. However, styles of argumentation differed. Salafist MPs, for instance, applied a rights-based approach, suggesting that women be given a monthly housing grant on an equal footing with a Kuwaiti male married to a non-Kuwaiti woman because

the Kuwaiti woman plays a fundamental role in building society and educating it, and should therefore get the right to obtain, along with her children, all services and benefits which the state provides so that she acquires her social and economic rights. ${ }^{48}$

In other proposals, two Salafist MPs based their argument on financial grievance when addressing the housing situation of different groups of Kuwaiti women (those married to non-Kuwaitis, divorcees, and single women without a guardian - lā mu'īl lahā $)^{49}$

An MP with a tribalist background emphasized women's equal rights with men, as well as financial grievance arguments. Women should own housing certificates of rented houses, he maintained, because of "the equal status [a Kuwaiti woman] share[s] with the Kuwaiti man in rights and duties." Referring to economic distress, he asserted that "divorced women are often not able to find suitable housing that secures her and the children's dignity." 50

Indicative of the importance of housing as a women's issue is the fact that the four female MPs rallied together and collaborated by forwarding a suggestion to establish a 500 million KD housing fund for women to safeguard women's interests in acquiring housing and loans independently of their male kin. ${ }^{51}$ This was the only case that gathered all four female legislators during the twoyear period they served as legislators. In the proposal, they sought to address "a range of problems related to divorced Kuwaiti mothers, widows, Kuwaiti women married to non-Kuwaitis and Kuwaiti women over the age of 40 who have lost both parents." Arguments were based on socio-economic realities: reform of the Housing Law was needed because it failed to consider women's growing participation in the labour market and correspondingly strengthened

48 Expression of support raised on 28 June 2009 by Khālid Sulțān ibn 'Īsā, Dr 'Alī al-'Umayr.

49 Khālid ibn 'Īsā and 'Alī al-'Umayr, expression of support, 1 July 2009. The FWAC approved in passing the proposal to parliament but changed the wording of "the single women with no guardian" (al-'azbä' lā mu'il lahā) to "the unmarried who has lost her parents" (al-ghayr mutazawwija faqadat al-abawayn). Second protocol of the FWAC dated 7 September 2009. Muhammad al-Huwayla, two expressions of support, 6 and 8 July 2009.

$51 \quad$ Law proposal, 28 April 2010. 
economic status, rising divorce rates in society, and the incapability of a male - for various health or employment-related reasons - to be the main financial provider of a household. 52

Interestingly, Islamist MPs argued along similar lines, although their points of reference differed slightly from those advanced by the four female MPs. For instance, a week after the women's housing plan, five Islamists - three Salafists and two Hadas-affiliated - also suggested that 500 million KD be used to establish a housing fund for widows, single women, and Kuwaiti women divorced from non-Kuwaitis, pointing out that "the current law premises the head of household be a Kuwaiti male [...] which has resulted in Kuwaiti women being deprived of housing benefits." 53 Shortly afterwards, five MPs - among them two who had voted against women's enfranchisement in 2005 - suggested a housing reform based on gender equality arguments. They emphasized Article 29 of the constitution, which stipulates equality between people, and referred to the Universal Declaration of Human Rights. The legislators pointed out that there are around 100,000 single Kuwaiti women, and maintained that

this number is rising, along with the numbers of divorcees and widows and single women over the age of 45 years whose rights should be recovered (irjā' huqūqihā al-mastūba) [...] through two venues: one which is linked with the individual and not gender whether male or female (murtabita bi-l-fard wa laysa bi-l-jins dhakaran aw unthā), and the other linked to the principle of equality (murtabita bi-mabda'al-musāwāt). ${ }^{54}$

In short, Islamist MP s alluded creatively to national and international law to emphasize equality as a principle, underlining individual rights independent of gender, and to suggest specific measures to address what they saw as social problems of single and divorced women whose rights should be restored, thus alluding to the pre-Iraqi occupation period.

$5^{2}$ Author interview with Dr Ma'ṣūma al-Mubārak, 22 April 2012.

53 The three Salafist MPs are Jumcān Zāāhir al-Ḥarbash, Muhammad Hāyif al-Muțayrī, and Walīd al-Ṭabāțabā'̄i. The two MPs affiliated with Hadas are Fayṣal al-Muslim and Falāḥ Muṭliq al-Ṣawwāgh. They proposed a "fund to safeguard housing for the Kuwaiti woman who does not benefit from the system of housing care" (mahfaza māliyya li-tawfir al-ri āya al-sakaniyya li-l-kuwaytiyya ghayr al-mustafida min nizāam al-ri ‘̄ya al-sakaniyya), 5 May 2010.

54 The five legislators were Musallam al-Barrāk and 'Alī al-Diqbāsī (voted against women's enfranchisement in 2005, members of Kutlat al-Amal al-Sha'bì), Dr Hasan Jawhar (voted for women's enfranchisement, Shi'a MP from Kutlat al-'Amal al-Sha‘bī), al-Ṣayfī Mubārak al-Ṣayfī, and Khālid al-Ṭāhūs. 
Demands for strengthening Kuwaiti women's access to housing rights gained political momentum with the Arab Spring. By March 2011, the government had issued decrees and laws in response to law proposals raised by MP s which had been pending in parliament for more than 20 years. The most significant reform during this politically volatile period was Law 2 of January 2011, which amended the 1993 Housing Law by including categories of Kuwaiti women who had not previously been able to access public housing: (1) Kuwaiti women married to non-Kuwaitis who had been naturalized and whose housing applications had been accepted in 1989; (2) Kuwaiti mothers married to non-Kuwaitis (i.e. with children); (3) Kuwaiti women married to non-Kuwaitis, residing in Kuwait but without children, provided that the couple have been married for more than five years; (4) divorced Kuwaiti women; and (5) single Kuwaiti women over 40 years. ${ }^{55}$

This legislative change affected around 68,00o women and their families. ${ }^{56}$ In total, it targeted most probably between 100,000 and 150,000 persons whogiven the small size of the electorate in Kuwait at around 385,000-400,000 - is a numerically substantial segment of the population.

iii

Kuwaiti Women Married to Non-Kuwaitis

The legal, social, and political malaise of Kuwaiti women married to non-Kuwaitis is part of the contentious bidun question, a larger social and politically potent problem related to the disputed and unresolved issue of the legal status of this segment of the population. It touches also fairly common experiences of problems related to citizenship, national belonging, and access to public welfare services following marriage between Gulf citizens who share transnational kinship and tribal bonds. ${ }^{57}$

Two of the four female MPs - Ma'șūma al-Mubārak and Rūlā Dashtī - had personal acquaintances of intermarriage. ${ }^{58}$ They brought to parliament life ex-

55 Kuwait Official Gazette (al-jarìda al-rasmiyya), 30 January 2011. All laws issued in Kuwait are announced in the Official Gazette and can be retrieved through the National Assembly's digitalized archive (www.kna.kw).

56 The reformed law affects an estimated 27,500 divorcees, 21,200 widows, 11,000 women married to non-citizens, and 8,600 unmarried women over the age of 41. The World Bank, "Opening Doors: Gender Equality and Development in the Middle East and North Africa", in Mena Development Report (Washington, United States: World Bank Publications, 2013), $79<$ https://openknowledge.worldbank.org/handle/10986/12552>.

The subject was discussed in a regional seminar entitled "The female citizen married to the noncitizen in the Gulf Cooperation Council: Rights and solutions" arranged by the Women's Research and Study Center at Kuwait University on 22 May 2013.

$5^{8}$ al-Mubārak is married to a Bahraini and has four children, all of whom are non-Kuwaiti. Dashtī has a Lebanese mother and a Kuwaiti father. 
periences which were articulated for the first time by women themselves in law proposals that aimed to strengthen the civil rights of Kuwaiti women married to non-citizens, and children born of mixed marriages. In six suggestions, the two MPs addressed, for instance, the situation of Kuwaiti women married to non-Kuwaitis, demanding that both the husband and the children of $\mathrm{Ku}$ waiti women married to non-Kuwaitis get access to health services, education, and the right to residency. ${ }^{59}$ Notably, only one of these claims was channelled through the FWAC. ${ }^{60}$ All other proposals that targeted Kuwaiti women married to non-Kuwaitis through the FWAC were raised by Islamists or independent MPs with tribal backgrounds.

For instance, Islamist MPs used gender equality based on international law, along with justice arguments embedded in Islam, in their demands for social and economic reforms to address the needs of Kuwaiti women married to nonKuwaitis ("God's grace has represented justice in Islam in the Kuwaiti constitution"), citing Articles 7 and 8 of the Kuwaiti Constitution, which guarantee the welfare and social security of citizens, and Article 9, which underlines that the family is the fundament of society (al-usra asās al-mujtama'), adding that:

Kuwaiti society is not represented only by Kuwaitis, but all who reside on its soil, and therefore the Kuwaiti woman is a foundational part of that society, and everything that has to do with her has a direct effect [...] on her children without distinguishing whether they are [born of ] a Kuwaiti or foreign father. [...] [i]t has become necessary to look at her problems as a woman, a mother and a wife married to a foreigner, for as these [problems] continue, they represent an injustice with regards to what the constitution has safeguarded in terms of equality (musāwāt), justice ('adl) and security (tuma'nina) as is alluded to by international human rights' organizations and the conscience of society at large, [in pursuit of ] the greatest effort to attain equality and justice within society. ${ }^{61}$

al-Mubārak raised four proposals alone and an additional two proposals with Dashtī. For details, see Tables 1 and 2 in my "Franchise in Kuwait after 2005."

60 al-Mubārak, expression of support, 10 February 2011. She suggested that a Kuwaiti woman married to a person whose citizenship is unidentified (implying a bidun) be able to register her children in public schools through a birth notification.

61 Three Islamist (Hadas-affiliated Fayṣal al-Muslim, on 15 June 2009; Hadas-affiliated Mikhlid al-'Āzimī, on 1 July 2009; and Salafist Dayfallāh Abū Ramiya, on 17 September 2009) and one independent MP with a tribal background (Sa'dūn al-'Utaybī, on 12 June 2009) raised four separate but identical expressions of support. Another two proposals arguing along the same lines were raised by two tribalists - Sa'dūn al-'Utaybī, on 12 July 2009, and 'Askar al-Anazī, on 8 October 2009. 
They suggest that a Kuwaiti woman should be able to act as a legal guardian (kafil) of her husband and children; that Kuwaiti women should be able to obtain the right to guarantee residence of their children (haqq kafālat abnä̉ih $\bar{a}$ min al-zawj ghayr al-kuwaytì); that Kuwaiti women married to non-Kuwaitis should receive child grants ${ }^{62}$ provided they are employed; that the non-Kuwaiti husband of a Kuwaiti woman should have the right to obtain a passport, a driving license, and access health services without fees; that her children should be granted the right to enroll in higher education in Kuwait; and that they be given priority in employment opportunities. ${ }^{63}$

In June 2011, several of these demands were addressed politically and implemented: Kuwaiti women were enabled to act as kafils and grant residency rights to their children and non-Kuwaiti husbands, and the children of Kuwaiti women married to non-Kuwaitis were able to receive free health service and public education up to 18 years. ${ }^{64}$

To sum up, demands raised by Islamist MP s reveal concerted efforts to articulate female agency and autonomy in acquiring housing and loans, as well as emphasizing a Kuwaiti woman's legal capacity to guarantee residence for her non-citizen family. Islamist MPs with overtly conservative views on gender relations referred to Qur'anic verses and international human rights conventions in underlining a Kuwaiti woman's need for a "house of her own", unmediated by her male kin. They thus emphasized gender relations in ways where Kuwaiti women, particularly those married to non-Kuwaitis and stateless bid$u n$, were seen as capacitated citizens. They referred to arguments of justice and gender equality, suggesting specific changes in current laws based on these principles. By extension, they argued for female autonomy in the distribution

62 The child's grant ('alāwāt awlād) is a financial direct transfer of $150 \mathrm{KD}$ (corresponding to roughly 496 USD or 426 Euro, July 2016 currency) paid directly to the Kuwaiti father by the state. Upon divorce, this sum continues to be paid to the father as mu'il (i.e. head of the family and thereby financially responsible), although the (divorced) mother has custody and daily care over the children. Children of Kuwaiti women married to non-Kuwaitis are not eligible to obtain child's grants.

63 Separate proposals raised by each of them on 15 June 2009, 1 July 2009, and 17 September 2009 respectively. The text of all four proposals is identical, although the proposals are raised individually and separately.

64 Interview with Ma'sūma al-Mubārak, 22 April 2012. Al-Mubārak pointed out that these changes came about as administrative measures issued by the Ministry of Education and the Ministry of Social Affairs, and not through parliamentary legislation, thereby weakening the strength of these rights. See "Kuwaiti women allowed to sponsor foreign husbands", Gulf News, 4 June 2011 <http://gulfnews.com/news/gulf/kuwait/kuwaiti-women-allowedto-sponsor-foreign-husbands-1.817223>. 
of public goods. In doing so, Islamist MPs supported strengthened civil rights for Kuwaiti women, unmediated by their male kin. Ideologically, Islamists advocate patriarchal family models, according to which males are the guardians of females. However, as legislators, Islamist MPs acted in ways that supported female civil and social rights - they acted as reluctant feminists, indeed.

\section{Exit the Female MPs from Parliament, 2011-2016: the Eclipse of Women's Issues}

After the exit of female MPs from parliament in December 2011, Islamist MPS stopped arguing along lines that focused on Kuwaiti women per se. In fact, their demands on behalf of women dropped sharply. The number of proposals raised through the FWAC dwindled; by the end of 2016, they still remained low. The decrease is partly related to lower overall proposals raised in parliament throughout 2012, when the emir dissolved the National Assembly, and elections were held in June and December. Another reason for fewer proposals raised in the FWAC until that date is that MPs preferred using other parliamentary committees to channel their demands, as will be pointed out below.

Proposals raised in the FWAC as of 2013 also reflected two other trends: a sharpened focus on the family, and the drafting of a Law on the Child. After women's exit from parliament, more than two years passed before an MP with a tribal background demanded the establishment of a family advisory centre. The latter would offer services to help support and maintain the family (khidmat tamāsuk al-usra [...] muhāafazatan 'alä kiyān al-usra). The centre would respond to the rising numbers of negative appearances (zawāhir silbiyya) in Kuwaiti society, such as problems between family members, domestic violence, and psychological strain. ${ }^{65}$ Later on, four proposals for enacting a Law on the Child were raised before the law passed unanimously in parliament on 24 March 2015.66 In these proposals, women figured primarily as wives and mothers rather than as citizens. In short, the profile of issues raised in the FWAC, characterized by an autonomous, woman-centred focus between 2006 and 2011, gave way to an emphasis on a woman's bonds and role in the family.

65 Muhammad al-Huwayla, 11 March 2014.

66 The first proposal was raised by the leader of the FWAC, Șāih 'Āshūr, with four other MPs on 4 June 2014. On the debate before the second vote in parliament was passed unanimously, see $a l-A n b \bar{a}, 25$ March 2015. 
Making a Difference in Their Presence: Women as Subtle Mobilizers?

How can we explain the rise and fall in the number of proposals addressing women's interests in the FWAC over a decade? Is this fluctuation related to women's presence, or are other factors at play? The review of the number and types of issues raised in the FWAC between 2009 and 2011 partly supports the thesis that the presence of female MPs made a difference. However, what comes out more clearly in the review is what may be described as an introverted interaction between female MPs and Islamist MPs, particularly those with a tribal background. In their capacity as main members of the FWAC, the women personified the role of custodians of women's interests. Tribalist MPs, for their part, found the FWAC a fertile legislative ground to reframe political objectives and bring them in line with arguments that shore up women's interests. Some of these objectives include the distribution of public goods to outlying tribal areas, the alleviation of poverty among tribal constituencies, and the dire legal and socio-economic conditions of mixed marriage between Kuwaiti women and non-citizens, including the bidun.

As caretakers of women's interests, female MPs saw the need to object, as in the case of the monthly grant proposal for unemployed women, or the formation of a specific law for women. From their perspective, monthly grants discouraged women's economic autonomy and limited their participation in the labour market, while the women's law jeopardized the normative principle of citizenship, according to which men and women are subject to the same laws. In most cases, the female MPs did not need to pressure for women-friendly reforms through the FWAC, because Islamist MP s acted as diligent protagonists of Kuwaiti women's civil and social rights.

Indirectly, the presence of women mobilized Islamists to address women's interests. Islamist MP s had addressed issues related to women before women were elected, but the number and frequency of proposals increased sharply after female politicians entered parliament, triggering Islamist MP s to act more energetically in profiling social and economic issues that affected women. Islamist MP's acts thus spoke louder than their words. Their responsibility towards tribal constituencies made the need to address economic deprivation, for instance, more important than their preferred ideals on gender roles (that males are providers for women and their guardians). Needs and deeds markedly trumped the ideals and gendered world view of Islamist MPs during women's presence in parliament.

The eclipse of the FWAC by 2013 as a political arena in which MPs addressed claims on behalf of women was not accompanied by the complete absence of proposals on policies targeting women's welfare. Male MPs, including Islamists, approached other committees, such as the Housing Committee, the 
Legislation and Legal Committee, and the Health, Social, and Labour Committee, instead of using the FWAC as an avenue for addressing women's issues. For instance, by March 2015, MPs had raised 16 law proposals to the Housing Committee, of which five (i.e. nearly a third) involved a Kuwaiti woman's legal capacity to be registered as the owner of a house. ${ }^{67}$ All five proposals were raised by MPs with tribal backgrounds. ${ }^{68}$

After the exit of women from parliament in December 2011, male MPs reverted to the parliamentary practice common prior to women's enfranchisement: proposals pertaining to women were once again split, dispersed, and presented to different parliamentary committees. In short, the FWAC ceased to be the main arena for addressing questions related to women after the female representatives lost their seats.

\section{Kuwaiti Islamists as Reluctant Feminists?}

Ideologically in favour of males as heads of households, and supportive of patriarchal family ideals, Islamist MPs nevertheless sought to bolster female autonomy in law proposals raised in parliament. They reframed a Kuwaiti woman's agency, arguing that a Kuwaiti woman should have equal civil rights and enjoy the same social welfare rights as a male Kuwaiti citizen.

Importantly, Islamist MP s did not support women's autonomy as capacitated citizens in order to bolster female civil rights per se. By raising claims on behalf of Kuwaiti women, Islamist MPs sought to address impoverished segments of the population who reside in disadvantaged constituencies in peripheral areas outside Kuwait City or who are affiliated to non-citizens and stateless residents through tribal kinship.

67 In the five proposals, MPs suggested amending the Housing Law in order to enable Kuwaiti women married to non-Kuwaitis, divorced women, single women over 40 years, and widows to have joint ownership of the house with the husband, by having the name of the wife rendered on registration forms.

68 Muhammad Nāșir al-Jabrī specifies the different categories of Kuwaiti women who should be allowed to own their own housing, 1 December 2013; Sa ūd Nashmī al-Ḥurayjī proposes that Kuwaiti women married to non-Kuwaitis should be able to get access to housing loans, 6 April 2014; Muḥammad Nāṣir al-Jābirī and Sacūd Nashmī al-Hurayjī suggest that both husband and wife be able to register as owners of a house, on the condition of five years or more of marriage, raised on 24 April 2014; 'Askar 'Uwayḍ al-'Anazī raised two proposals on 6 July 2014 and 7 December 2014 suggesting that a man and a woman be able to register as owners of a house in order to safeguard the economic interests of a male or a female widow. 
The potency of tribal politics has run as a thick thread through the acts of MPS in the FWAC over the past decade. In my analysis, I have grouped three women-unfriendly entities affiliated with Hadas, Salafist, and tribalist groups, and labelled them 'Islamist.' Although Islamist MP s share a common patriarchal world view, they differed in the way they approached women's issues in the FWAC. Hadas MPs raised proposals in line with conservative values on limiting women's working hours at night, and a separate law for Kuwaiti women's civil rights. By contrast, Islamist MPs with a tribalist background raised more frequently proposals of a specific socio-economic character.

Gwenn Okhurlik points out differences among Islamists with reference to Islamist candidates running before the June 2012 elections:

the so-called Islamist-led opposition is far from a monolithic coalition: Some Islamists are ideologues, others are not. Religious fervor was not a central campaign call. Islamist candidates proved themselves to be better organized and more politically savvy, articulate, and eloquent. ${ }^{69}$

One of these politically articulate and savvy Islamist tribalists is Musallam alBarrāk (b. 1956), who has won the heart of the nation. As MP in 2005, he voted against women's enfranchisement. Later, as an MP between 2006 and 2012, he nevertheless proposed expanding Kuwaiti women's autonomy. ${ }^{70}$ The Kuwaiti

69 Gwenn Okruhlik, "The Identity Politics of Kuwait's Election", in Kuwait's Moment of Truth, ed. Marc Lynch, The Project on Middle East Political Science (POMEPs) (Washington, DC: Institute of Middle East Studies, George Washington University, 2012) <http:// pomeps.org/wp-content/uploads/2012/11/POMEPS_BriefBooklet15_Kuwait_web.pdf>, 22. On what she describes as pious, popular, and pragmatic Islamists, see Alessandra L. Gonzales, Islamic Feminism in Kuwait: The Politics and Paradoxes (New York: Palgrave Macmillan, 2013), 45-49.

70 Member of the Popular Action Front (Kutlat al-Amal al-Sha'bì), al-Barrāk represented peripheral areas (the 14th electoral district, which later changed to the 4 th). He was first elected by less than 1,500 votes in 1992, and has repeatedly been voted in as MP. At the February 2012 elections he received more than 30,000 votes - the highest number of votes ever registered in Kuwait's electoral history. Al-Barrāk lost parliamentary immunity after participating in the storming of parliament in November 2011, and was sentenced to jail for two years in 2015 on charges of harming security and undermining the status of the emir. Whereas other political prisoners were released after being pardoned by the emir in September 2016, al-Barrāk served two years in prison, and was released in April 2017 (The New Indian Express, 21 April 2017 <http://www.newindianexpress.com/world/2017/apr/21/ kuwaits-most-prominent-opposition-figure-musallam-al-barrak-freed-from-prison-159 628o.html>). Michael Herb, Kuwait Database <http://kuwaitpolitics.org/DataPage506. htm>. See also "al-Barrak not included in Emiri pardon, says ex-Justice Minister", Gulf 
social media sphere provides testimony to his popularity. Kuwaiti parliamentary documents provide, likewise, evidence of his efforts, together with allies, at raising demands on women's interests.

Some Islamist groups, in particular Hadas male members and doctrinaire Salafists, have agitated, sometimes successfully, for the inclusion of principles of Islamic jurisprudence (sharî $a$ ) in the public sphere. ${ }^{71}$ They have demanded that female MPs be veiled, and in 2009 they opposed the introduction of a female police force. ${ }^{72}$ However, the tribalist element in the Kuwaiti Islamist political scene has made its impact on restructuring electoral politics, rendering Hadas and affiliates less assertive actors in defining issues framed as 'Islamic' or 'Islamist' in Kuwait. Therein lie new spaces for manoeuvring women's interests and interpreting politics in a legislative environment that form policies concerning the lives of women. ${ }^{73}$

\section{The Incompleteness of Tribalists' and Women's Citizenship}

Naturalized after Kuwaiti independence in 1961, tribalists from outer districts are, according to Nathan Brown, "relatively late-arriving citizens."74 Enfranchised only in 2005, Kuwaiti women are latecomers, too, in terms of when they began participating in politics. Women and tribalists have both been marginalized social categories who, in the past decade, have become legitimate participants by entering political representative spheres. The politics of presence thesis applies therefore as much to the entry of tribalists to parliament as it does to women. Both have incomplete citizenship, possessing only underdeveloped, mediated, and contingent rights. Hence the interaction between and among these two categories of players offers fresh modes of articulating

News, 8 September 2016 <http://gulfnews.com/news/gulf/kuwait/al-barrak-not-includedin-emiri-pardon-says-ex-justice-minister-1.1893314> .

71 Islamist MPs succeeded in inferring that a woman must abide by shari $a$-based fundaments and rules in Article 1 of the 1962 Electoral Law during the voting session on women's enfranchisement in 2005.

"Kuwait Police Open to Women but Islamists Opposed", Khaleej Times, 22 April 2009, retrieved from Women's Un Report Network (WURN) <http://www.wunrn.org/news/2009/ 04_09/04_20_09/042009_kuwait.htm>.

73 Jennifer Curtin, "Advancing Women's Interests in Formal Politics", in The Politics of Women's Interests: New Comparative Perspectives, eds. Louise Chappell and Lisa Hill (London and New York: Routledge, 2006), 93-94.

74 Nathan Brown, "Kuwait's Short 19th Century", in Kuwait's Moment of Truth, ed. Marc Lynch, The Project on Middle East Political Science (POMEPS) (Washington, DC: Institute of Middle East Studies, George Washington University, 2012) <http://pomeps.org/wpcontent/uploads/2012/11/POMEPS_BriefBooklet15_Kuwait_web.pdf, 12>. 
politics, including politics on women's interests as evidenced by proposals raised in the FWAC. ${ }^{75}$

Seen from a Rokkanian political cleavage perspective, the political participation of women and tribalists revolves around a classical urban-rural socioeconomic cleavage. ${ }^{76}$ The hadar (sedentary) and badu (tribal) distinction conceals the fact that 99 per cent of tribal groups have become urbanized since the 1970s, although the state's housing policies have systematically relegated them to the periphery. ${ }^{77}$ Female MP s represented their sex but they also represented the educated and socio-economically privileged strata of the urban demos part of the citizenry. ${ }^{78} \mathrm{~A}$ liberal cosmopolitan middle-class world view and American-style entrepreneurship coloured the political values of the four women, who were born and raised in central parts of Kuwait City and who earned their PhDs from universities in the United States after extended stays and cultural experiences abroad.

By contrast, tribalists are born in, come from, or represent peripheral areas, be it the outskirts of Kuwait City or the Kuwaiti border areas. Some of the MPs with a tribalist background share the educational, cultural, and globalized credentials of urban Kuwaitis, but the majority are less experienced with the urbanized cultural and merchant elites of the centre. However, they have acquired considerable experience as local administrators and politicians, and some win in tribal primaries (i.e. gatherings where candidates are chosen or elected).$^{79}$ The review of FWAC proposals indicates that some MPs with a tribal background managed to reformulate claims in ways that attended to several objectives without losing credibility among supporters because their demands catered to women's interests in ways that also addressed socio-economic grievances at large.

75 The term 'incomplete citizenship' is used and defined by Jill Vickers, "The Problem with Interests: Making Political Claims for 'Women”, in The Politics of Women's Interests: New Comparative Perspectives, eds. Louise Chappell and Lisa Hill (London: Routledge, 2006), 19, 35 .

76 Stein Rokkan and Derek W. Urwin, Economy, Territory, Identity: Politics of West European Peripheries (London: Sage, 1983), 118-24.

77 Farah Al-Nakib, "Revisiting Haḍar and Badū in Kuwait: Citizenship, Housing, and the Construction of a Dichotomy", International Journal of Middle East Studies 46, no.1 (2014), 6, doi:10.1017/Soo20743813001268.

78 Rania Maktabi, "The Politicization of the Demos in the Middle East: Citizenship between Membership and Participation in the State" (PhD diss., University of Oslo, 2012) <https:// www.duo.uio.no/handle/10852/34924>, 45-54.

Tétreault, "Political Activism", 281-82. 
The scholar on Islamist movements Nathan Brown characterized tribalist MPs as "noisy claimants on constituents' behalf", and portrayed them as political milking machines for public welfare benefits. ${ }^{80}$ Such a sketchy characterization fails to credit the context in which claims by tribalists are raised, and which political scientists usually perceive as aggregation and articulation of legitimate interests. In seeing tribalists as predominantly seekers of short-term material gains, Brown runs the risk of discrediting claims resulting from structural discrimination and exclusion, most importantly from the Kuwaiti state's rentier-embedded welfare programmes, which have, until the turn of the millennium, been overly skewed in favour of hadar constituencies.

Political scientist Jill Vickers points out that "when feminists make demands on behalf of 'women', they are declared as claiming to be a 'special interest'."81 Likewise, demands for amending the 1959 Nationality Law can be seen as a 'special interest' among Kuwaiti rulers and those included as legitimate citizens. Failing to achieve amendments in the nationality law, MPs of a tribal background have sought to improve the position of marginalized segments of their constituencies through proposals that address socio-economic hardship. While the legal status of the bidun remains contested, demands for a more inclusive citizenry is a recurrent claim that has increased in force. ${ }^{82}$ For instance, a search for "nationality law" (qānūn al-jinsiyya) in Kuwaiti parliamentary documents reveals the following distribution of questions related to citizenship, suggestions and demands for amendments of the Kuwaiti nationality law: 9 proposals between 1966 and 1986, 53 proposals between 1992 and 2006 (until women were enfranchised), and 62 proposals between 2008 and 2015. In short, the number of questions and claims related to nationality law raised by citizens in parliament on behalf of those with incomplete citizenship - women and stateless bidun - have gradually increased.

Taken together, these figures are indicative of the social pressure shored up by stateless bidun and their supporters who mobilized collectively for the first time after the Arab Spring. Demands for change in the nationality law and inclusion as citizens were met with repression, including imprisonment and the revoking of citizenship. ${ }^{83}$ In other words, claims by tribalists for reforms in

\footnotetext{
$80 \quad$ Brown, "Kuwait's Short 19th Century", 8-9.

$81 \quad$ Vickers, "The Problem with Interests", 19.

82 Importantly, not all claims seek to amend the nationality law in more inclusionary ways, and some are raised to maintain the current law.

83 "Kuwait Revokes Citizenship of 18 Nationals", POMED Project on Middle East Democracy Blog, undated (30 September 2014) <http://pomed.org/blog-post/kuwait-revokes-citizenship-of-18-nationals/>.
} 
social policies that address their 'special interest', that of statelessness or mixed marriage, may well be seen in light of the Kuwaiti regime's restrictive practices in issues related to nationality and citizenship.

\section{Conclusion}

It might sound like an oxymoron that Islamist MPs acted as feminists after $\mathrm{Ku}-$ waiti women were enfranchised in 2005. The evidence from the parliamentary records, however, shows that they did exert pressure through the parliamentary Family and Woman's Affairs Committee to strengthen Kuwaiti women's rights. Several of them did so reluctantly, judging from some of these MPs' opposition to granting Kuwaiti women political rights in 2005 .

Substantiating the 'politics of presence' thesis, women and Islamists of a tribalist background interacted in ways that resulted in a noticeable increase in proposals raised in support of women's interests between 2009 and 2011. Islamist MP s argued that Kuwaiti women should be able to act as legal guardians (kafil) of their husbands and children; should be brokers of material welfare services such as free education, health services, and jobs in the public sector; and should get equal access to financial commodities such as public housing schemes. Particularly prominent were issues pertaining to housing and the welfare rights of Kuwaiti women married to non-Kuwaitis.

Two reflections can be drawn from the Kuwaiti case with regards to women's political representation in a conservative authoritarian setting with tribal groups participating in electoral politics. First, simply assuming that the presence of women in representative institutions is a good thing for strengthening women's rights in politics is problematic. With reference to the discussion on whether it is women's presence in parliament or acts that support women's issues, irrespective of women's presence, that leads to women-friendly reforms, my investigation of acts in the FWAC supports both standpoints. Acts (i.e. proposals on women's issues) increased dramatically as numbers (i.e. the presence of women parliamentarians) increased. Notably, Islamist MPs were prolific in raising proposals in the FWAC before women were elected. However, the entry of women in 2009 led to a sharp increase in proposals raised predominantly by Islamist MPs.

Second, when Islamist MPs with a tribalist background use rights-based arguments to emphasize women's rights in sharing public social welfare services on an equal basis with males, then the transnational power of international 
conventions on domestic politics has left a legacy in Kuwaiti politics. ${ }^{84}$ The needs of Kuwaiti women married to non-Kuwaitis figured heavily in the proposals raised in the FWAC: around a third of all issues raised in the FWAC over a decade addressed this segment of Kuwaiti women. Given the Kuwaiti regime's exclusionary practices in contracting the size of the citizenry, and the revoking of nationality as a means of silencing political dissent, the naturalization of stateless bidun is not foreseeable in the short-run. However, Kuwaiti women have mobilized in demanding their right to pass on Kuwaiti nationality to their children, and may be "first in line" to expand their citizenship over the stateless bidun.

Historical evidence in Western and MENA states indicates that patriarchal nationality laws are sticky. Several decades separate women's enfranchisement and the amendment of patriarchal nationality laws to include women's right to pass on their nationality to their children. ${ }^{85}$ The establishment in 2011 of Kuwaiti Women with No Limits, a civil society group that pressures for amendments in the Kuwaiti nationality law, is a case in point. The organization is headed by three women: a professor in engineering, a professor in law, and a woman of tribal background married to a bidun. ${ }^{86}$ Such cross-cutting organizational alliances would appear to indicate that pressure groups may grow stronger in time. The gendered face of statelessness and the incompleteness of Kuwaiti women's citizenship are bound to grow stronger and more violent in the years to come, hand in hand with enfranchised women and mobilized tribalists.

84 Kathryn Sikkink, Thomas Risse, and Steve C. Ropp, eds., The Power of Human Rights: International Norms and Domestic Change (Cambridge: Cambridge University Press, 1999), 10.

85 In Norway, women were enfranchised in 1913; the patriarchal nationality law was amended in 1979. In Egypt, women received political rights in 1956; the patriarchal nationality law was amended in 2004 (in 2011 for Egyptian women married to Palestinians).

86 Interview with author, leader, Khulūd al-Hindī, vice leader, 'Aliya al-Dulaymī, and legal advisor, Fāțima al-Ḥewayl, 9 March 2015. 